\title{
STUDIES ON SWEET BASIL MOSAIC VIRUS DISEASE AND ITS CONTROL BY USING SOME ESSENTIAL OILS
}

\author{
F.E.M Saleh ${ }^{*}$ A.A.S. Abdel-Kader ${ }^{*}$ and Amal M.I. Eraky ${ }^{* *}$ \\ * Medicinal and Aromatic Plants Research Department, Horticulture Research Institute, \\ Agricultural Research Center (ARC), Giza, Egypt. \\ ${ }^{* *}$ Department of Plant Pathology, Faculty of Agriculture, Assuit University, Egypt.
}

ABSTRACT: The current study, the mosaic virus disease of Ocimum basilicum L. (sweet basil) was identified and the different effects of three essential oils on growth, oil content and composition as well as reducing CMV disease symptoms of sweet basil plants in vivo. During 2012 season, natural occurrence of mosaic virus disease was observed on sweet basil in Assiut, Egypt. The causal agent of basil mosaic disease was detected as cucumber mosaic virus (CMV) by PCR product that revealed presence of approximately expected size $(\sim 781$ bp) in naturally infected basil. Therefore, a field experiment was carried out during two successive seasons 2013 and 2014 on sweet basil plants at the Experimental Farm of Arab El Awamer Agricultural Research Station, Assiut Governorate, Egypt. Ten treatments of three essential oils extracted from lemongrass (Cymbopogon citratus), rosemary (Rosemarinus officinalis) and peppermint (Mentha piperita L.) plants were applied as foliar spray at $1 \%$ concentration before and after inoculation with isolated virus and two controls (healthy and infected plants) were arranged in a randomized complete block design with three replicates. Results revealed that application of essential oils under field condition improved growth and yield (branches, weight of fresh and dry plant (g/plant) as well as essential oil percentage),

Scientific J. Flowers \& Ornamental Plants, 5(1):1-13 (2018).

Received: 3/3/2018

Accepted: $18 / 3 / 2018$ reduced the CMV disease symptoms compared to untreated infected control. As well as significant increase in total identified of essential oil composition of basil plant. Whereas the treatment with rosemary oil before and after inoculation respectively, was increased in myrcene, linalool when applied before inoculation and with a great increase in 1 , 8-cineole when applied after inoculation. Also a great increase was related to peppermint oil treatment for eugenol, myrcene and 1, 8cineole \% before inoculation comparable to untreated infected plants. While, using of peppermint oil significantly increased number of branches, fresh and dry weights, essential oil content and composition when applied before inoculation with virus compared to infected and healthy controls. Lemongrass essential oils exhibited a moderate protective effects. Generally, applying of rosemary essential oil as curative seemed to be superior for improving branches, weight of fresh and dry plant (g/plant), and essential oil percentage and composition comparing to other treatments.

Key words: Ocimum basilicum L., mosaic virus, essential oils, lemongrass, rosemary, peppermint. 


\section{F.E.M Saleh et al.}

\section{INTRODUCTION}

Sweet basil (Ocimum basilicum L.) is an annual, aromatic, herbal plant, belonging to the family Lamiaceae. The aromatic basil leaves and flowers, as well as the essential oil distilled from the herb are used as aromae for food, perfume and cologne production and in medical therapy. Basil oil is a mixture of numerous compounds and its composition is extremely rich and varied. Some constituents of the volatile oil distilled from the basil herb, such as linalool, 8-cineole, methyl chavicol, eugenol, or camphor, documented biological activity (Kaledin et al., 2009).

Plant viruses have been a major problem in many crops, vegetables and ornamental plants, which seriously affect product quality and yields of different crops (Zhao et al., 2017). The effect of phytopathogenic viruses on various aromatic plants has been found to be responsible for significant variations in the composition of marketed essential oil (Hudaib et al., 2001 and 2002). A survey of the literature revealed that the plant viruses known to infect basil worldwide are: Wintermantel and Natwick (2012) reported the natural occurrence of Alfalfa mosaic virus (AMV) on basil in California. Khan et al. (2011) identified a new isolate of CMV subgroup II and designated as CMV-Basil as natural occurrence of mosaic disease in Aligarh, India. In India, the association of $\mathrm{CMV}$ with the mosaic disease of basil was investigated based on biological and serological characteristics (Raj et al., 1997). Cucumber mosaic virus (CMV) causing mosaic disease in basil was reported for the first time in Italy by Marini (1955).

Regarding phytopathogenic viruses, various substances of natural and synthetic origin have been assessed for their antiphytoviral activity. Essential oils were also reported for their plant antiviral activity e.g. carrot leaf oil showed moderate antiviral activity against tobacco mosaic virus (Font et al., 2004). Tea tree oil showed efficiency against tobacco mosaic virus (Duffus, et al., 1996). Ismail (1994) studied the antiviral activity of lemongrass and 3 other essential oils against potato virus $\mathrm{Y}$ in vitro and in vivo. Zhu and Qiu (1989) screened 30 species that are antiviral effective against cucumber mosaic virus (CMV).

Essential oils are natural products obtained from plants. They were formed by varied and complex volatile mixtures of chemical compounds, with predominance of terpene associated to aldehyde, alcohols and ketone. Rosmarinus officinalis (Vent.) Boiss is a genus of plant in the Lamiaceae family. A genus is generally known under the name "rosemary" and is commonly used as a flavoring agent and as a medical plant. The main constituents of the essential oils in aerial parts were $\alpha$-pinene, camphene, 1,8 cineole, camphor, linalool, limonene and other components in amounts less than 2\% (Moghadam, 2015). Lemongrass (Cymbopogon citratus) is an aromatic plant belonging to the Gramineae family (Akhila, 2010). Lemongrass contains 1 to $2 \%$ essential oil on a dry basis, mainly citral. Other unusual active components are limonene, citronellal, ß-myrcene and geraniol (Tajidin et al., 2012). Regarding chemical characterization of mint (Mentha spp.), the major essentail oil constituents detected were: 1, 8-cineole, carvone, limonene, linalool, linalyl acetate, menthol, menthone, menthyl acetate, and piperitenone oxide and linalool (78.5\% in CM 24- $M$. arvensis) (Gracindo et al., 2006).

Our study was to identify the virus infected Sweet basil (Ocimum basilicum L.) using RT - PCR to evaluate the potential antiviral agents of some essential oils (lemongrass, peppermint and rosemary) for the protection of sweet basil plants from mosaic virus infection and estimate the effects of these essential oils on chemical constituents of sweet basil essential oil, yield and growth under field conditions. 


\section{MATERIALS AND METHODS}

\section{1- Source and identification of the causal pathogen:}

Infected basil plants were collected from Arab El Awamer, Agriculture Research Station, Assiut, Egypt, during 2012 growing season. Total RNA was isolated using Tri reagent method as described by Abdulla and Ali (2012) in Molucular Biology Unit, Assiut Univ. Assiut, Egypt. Reverse transcription - polymerase chain reaction (RT - PCR) was performed using specific primer to amplify coat protein gene of CMV, it includes forward primer (5'TGCTTCTCCRCGARWTTGCGT-3`) and reverse primer (5`CGTAGCTGGATGGACAACCCG-3`) as described by Milojevic et al. (2010). The PCR was done in $25 \mu \mathrm{l}$ reaction mixture. The PCR conditions were: initial template $95^{\circ} \mathrm{C}$ for $15 \mathrm{~min}$. followed by 45 cycles consisting of denaturation at $95^{\circ} \mathrm{C}$ for 40 sec., Primers were annealing at $50^{\circ} \mathrm{C}$ for $40 \mathrm{sec}$. and extension at $72^{\circ} \mathrm{C}$ for 40 sec. and final extension at $72{ }^{\circ} \mathrm{C}$ for $10 \mathrm{~min}$. The electrophoresis of PCR product was in 1.0\% agarose gel.

\section{2- Plants and growing conditions:}

A pot experiment was conducted during the growing seasons of 2013 and 2014 at the Experimental Farm of Agricultural Research Station, Arab-El-Awamer, Assiut Governorate, Egypt. Seeds of local variety of Ocimum basilicum L. were obtained from the Medicinal and Aromatic plants Department, Horticulture Research Institute, Ministry of Agriculture, Egypt, were sown in a nursery in the first week of March in both seasons. After 40 days from germination, the uniform seedlings of $10-15 \mathrm{~cm}$ height were transplanted (one seedling/pot) into plastic pots (30 cm diameter and $40 \mathrm{~cm}$ height) filled with a loamy sand soil; Physiochemical analyses of the used soil were done according to Jackson (1973) and Black et al. (1982) (Table, 1). The experiment was arranged in split-plot based on randomized complete block design (RCBD) with three replications. Each replication contained ten treatments, The main-plot included T1=spray with essential oil before inoculation with virus and $\mathrm{T} 2=$ spray with essential oil after inoculation with virus, and the sub-plot treatment included application of the different essential oils of Cymbopogon citratus L, Mentha piperita and Rosmarinus offincinalis at $1 \%$ concentration as foliar spray and two controls (healthy plants, artificial infected plants). All necessary cultural practices and plant protection measures were followed uniformly for all the pots during the entire period of experimentation. The plants were cut twice during each growing seasons, by cutting the plants $15 \mathrm{~cm}$ above the soil surface. The plant height, number of branches, total fresh and dry weights of the herbs (g/plant), were then recorded by standard methods.

\section{3- Essential oil analysis:}

The essential volatile oils of dry herb were determined at the stage of $90 \%$ flowering and distilled by hydrodistillation according to British Pharmacopoeia (1973).The percentage of the volatile oil were then calculated on the base of dry weight of the herb. The extract essential oils from Ocimum basilicum L. were collected from the first, and second cuttings for each treatment to identify the chemical constituents.

\section{4- Gas chromatography-mass spectrometry (GC-MS):}

The volatile oils obtained from the dry herb were analyzed using Ds Chrom 6200 Gas Chromatograph equipped with a flame ionization detector for separation of volatile oil constituents. The analysis conditions were as follows:-

The chromatograph apparatus was fitted with capillary column BPX-5, 5\% phenyl (equiv.) polysillphenylene-siloxane $30 \mathrm{~m} \mathrm{x}$ $0.25 \mathrm{~mm}$ ID $\mathrm{x} 0.25$ film- Temperature program ramp increased with a rate of $10{ }^{\circ} \mathrm{C} /$ min from $70^{\circ}$ to $190{ }^{\circ} \mathrm{C}$. Flow rates of gases were nitrogen at $1 \mathrm{ml} / \mathrm{min}$, hydrogen at 30 $\mathrm{ml} / \mathrm{min}$ and $330 \mathrm{ml} / \mathrm{min}$ for air. Detector and 
Table 1. The physical and chemical characteristics of the experimental soil.

\begin{tabular}{llcc}
\hline Soil properties & values & Soil properties & values \\
\hline Particle size distribution & & Soluble cations(meq/l) & 1.70 \\
$\quad$ Sand (\%) & 21.3 & $\mathrm{Ca}^{++}$ & 0.70 \\
Silt (\%) & 54.2 & $\mathrm{Mg}^{++}$ & 2.1 \\
Clay (\%) & 24.5 & $\mathrm{Na}^{+}$ & 1.2 \\
Soil texture & Salty clay loam & $\mathrm{K}^{+}$ & 2.1 \\
Field capacity (\%) & 9.92 & $\mathrm{Soluble}^{+}$ & 0.6 \\
Total nitrogen (\%) & 0.23 & $\mathrm{CO}_{3}+\mathrm{HCO}_{3}$ & 3.0 \\
Total CaCO & $(\%)$ & $\mathrm{SO}_{4}$ & 0.12 \\
Organic matter (\%) & 1.78 & $\mathrm{Cl}^{-}$ & 0.15 \\
PH (1:2.5watersuspension) & 1.10 & $\mathrm{Total}^{-}$ & potassium (\%) \\
EC m mhos/cm (1:5) & 8.0 & Total Phosphorus (\%) & \\
\hline
\end{tabular}

injector temperatures were $300^{\circ} \mathrm{C}$ and 250 ${ }^{\circ} \mathrm{C}$, respectively. The obtained chromatogram and report of GC analysis for each sample were analyzed to calculate the percentage of main components of volatile oil.

\section{5- Antiviral activity of essential oils:}

\section{a- Mechanical inoculation for plants:}

Basil cmv infected leaves were ground in $0.1 \mathrm{M}$ phosphate buffer at $\mathrm{pH} 7.5$ (1:3, w: v) in chilled mortars. Before inoculation, basil leaves were dusted with 500-mesh carborundum. The ground virus inoculum was gently rubbed over the leaf surfaces using pad of cotton gauze dipped in the inoculum.

\section{b- Preparing samples and extracts:}

The essential oils of three plants (Cymbopogon ctratus L, Mentha piperita and Rosmarinus offincinalis) were obtained through hydrodistillation of plants grown in the Experimental Farm of Agricultural Research Station, Arab-El-Awamer, Assiut Governorate, Egypt, and used at 1\% concentration as foliar spray treatments.

\section{6- Statistical analysis:}

The obtained data were subjected to statistical analysis of variance using "F" test and means were compared by using least significant differences (L.S.D.) at 0.05 level according to Sendecor and Cochran (1973).

\section{RESULTS AND DISCUSSION}

\section{1- Identification of the causal pathogen:}

The viral symptoms in sweet basil (Ocimum basilicum L.) grown in Assiut, Egypt, were consisted of mosaic and leaf distortion. PCR product (Fig., 1) revealed presence of the expected size fragment

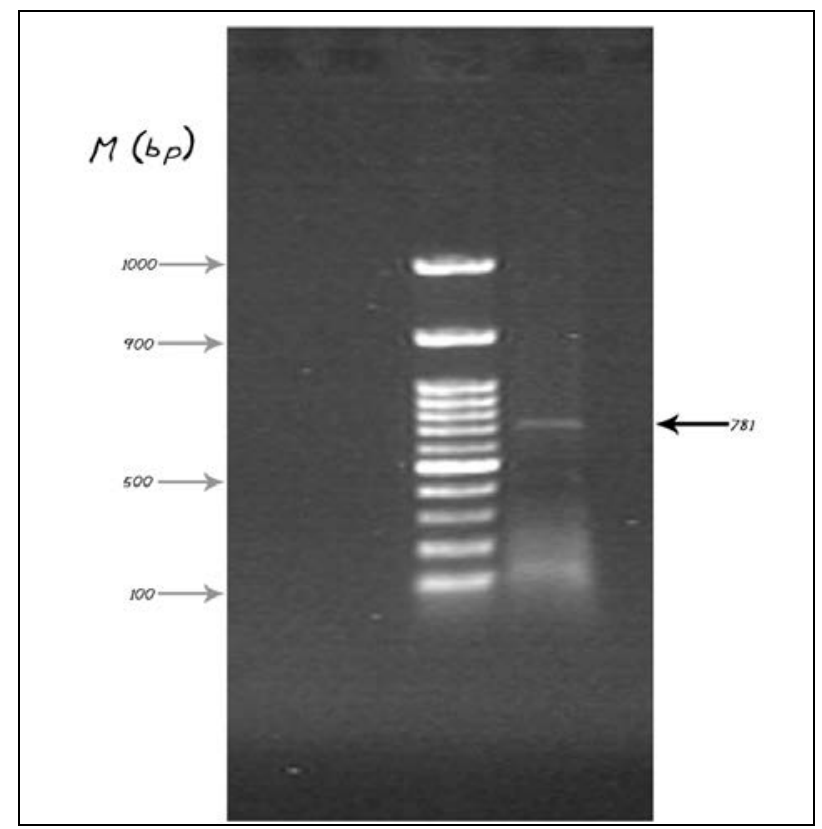

Fig. 1. Gel electrophoresis of PCR products amplify using specific primers for amplifying $\mathrm{CP}$ gene of CMV. 
approximately ( 781 bp) in naturally infected basil, but it was absent in healthy plant. This description was identified as Cucumber mosaic virus by RT-PCR using coat protein gene specific primers of CMV. Similar results were obtained by Marini (1955) when he found CMV affecting basil naturally. Khan et al. (2011) identified the natural occurrence of mosaic disease which was observed on basil (Ocimum sanctum L.) in Aligarh, India, during 2008; Cucumber mosaic virus (CMV) was detected by RTPCR using coat protein gene specific primers of CMV.

\section{2- Vegetative growth and yield of basil plants:}

Statistical analyses of vegetative growth and yield of basil plants revealed significant differences between healthy and CMVinfected plants (Tables, 2 \& 3). Significant reductions in number of branches, weight of fresh and dry plant (g/plant) in the first and second cuts in both cultivated seasons were due to CMV infection. However, a nonsignificant reduction in plant height was observed. A similar effect of the CMV in both tobacco and melon plants was observed, Shoot growth was slightly inhibited in CMVMP-expressing plants; however, root mass of the transgenic plants was about $50 \%$ of that measured for the controls (Shalitin et al., 2002). A striking alteration in resource allocation was observed in TMV-MPexpressing tobacco plants, this effect was reflected in significant inhibition of root growth and a low root-to-shoot ratio (Lucas et al.,1993 and Balachandran et al., 1997).

Comparison of data presented in Tables (2 \& 3) showed that foliar spray of basil plants with essential oils extracted from lemongrass, peppermint and rosemary plants at $1 \%$ under field condition significantly increased number of branches, fresh weight, dry weight and essential oil percentage of sweet basil compared to untreated infected plants before and after inoculation with virus in both seasons.
The maximum plant values were observed with rosemary oil treatment while the minimum was recorded in infected plants without treatment. Treatments, with peppermint as protective (treatment after inoculation with virus) and rosemary essential oil as curative (treatment after inoculation with virus) gave the highest values of number of branches, weight of fresh and dry plant (g/plant)with significant differences among them in the first and second cuts in both cultivated seasons. These results agree with those of Niakan and Saberi (2009) on phalaris weed who stated that Eucalyptus increased root and shoot length. Also, Eucalyptus oils seemed to be superior for improving vegetative growth, total head yield with large and heavier heads of cabbage and cauliflower plants (Abd Alla and El-Shoraky, 2017).

\section{3- Essential oil (EO) content and composition of basil plants:}

The results presented in Table (3) showed oil content of CMV-infected basil plants compared to that of healthy control and other treatments (lemongrass, peppermint and rosemary essential oils) suggesting that the disease may affect abundance and efficacy of secretive tissues. During present investigation, quality of essential oil (EO) was greatly affected and EO composition resulted was severely altered, with a large decrease in total identified percentage of infected basil plants (from 92 to 80\%) (Fig. 2 a \& b). Cucumber mosaic virus infection drastically changed the chemotype of the basil oil, in particular, 1, 8-cineole and linalool, the two main constituents and aroma contributors of sweet basil were reduced from 7.67 to $2.95 \%$ and from 44.24 to $33.09 \%$, respectively in CMV infected plants, whereas eugenol was slightly increased (Table, 4). Bruni et al. (2016) reported the effects of alfalfa mosaic virus (AMV) infection on essential oil (EO) content and composition of a sweet basil, suggesting that morphological alterations induced by the disease may affect abundance and efficacy of secretive tissues, 
Table 2. Effect of essential oils treatments on plant height, number of branches/plant, fresh weight (g/plant) of infected Ocimum basilicum L. during 2013 and 2014 seasons.

\begin{tabular}{|c|c|c|c|c|c|c|c|c|c|c|c|c|}
\hline \multicolumn{13}{|c|}{ Plant height (cm) } \\
\hline \multirow{3}{*}{$\begin{array}{c}\text { Treatments } \\
\text { (B) }\end{array}$} & \multicolumn{6}{|c|}{ First season } & \multicolumn{6}{|c|}{ Second season } \\
\hline & \multicolumn{3}{|c|}{ First cut } & \multicolumn{3}{|c|}{ Second cut } & \multicolumn{3}{|c|}{ First cut } & \multicolumn{3}{|c|}{ Second cut } \\
\hline & $\begin{array}{l}\text { T1 } \\
\text { (A) }\end{array}$ & T2 & Mean & T1 & T2 & Mean & T1 & A) & Mean & T1 & $\mathbf{T} 2$ & Mean \\
\hline Healthy & 63.00 & 63.00 & 63.00 & 63.33 & 63.33 & 63.33 & 52.89 & 52.89 & 52.89 & 54.78 & 54.78 & 54.77 \\
\hline Infected & 58.50 & 58.50 & 58.50 & 61.33 & 61.33 & 61.33 & 49.44 & 49.44 & 49.44 & 50.89 & 50.87 & 50.88 \\
\hline L. grass & 60.00 & 62.33 & 61.17 & 61.00 & 63.33 & 62.17 & 52.11 & 53.78 & 52.94 & 54.89 & 55.00 & 54.95 \\
\hline Peppermint & 61.33 & 63.67 & 62.50 & 63.33 & 63.55 & 63.45 & 52.44 & 55.00 & 53.72 & 54.22 & 56.97 & 5.59 \\
\hline Rosemary & 63.00 & 65.33 & 64.17 & 65.00 & 66.61 & 65.83 & 53.22 & 59.53 & 56.41 & 55.64 & 58.56 & 7.10 \\
\hline Mean & 61.17 & 62.57 & - & 62.80 & 63.56 & - & 52.04 & 54.13 & - & 54.09 & 55.23 & - \\
\hline L.S.D. & $\begin{array}{c}\text { A } \\
\text { N.S }\end{array}$ & $\begin{array}{c}\text { B } \\
\text { N.S. }\end{array}$ & $\begin{array}{l}\text { AB } \\
\text { N.S. }\end{array}$ & $\begin{array}{c}\text { A } \\
\text { N.S. }\end{array}$ & $\begin{array}{c}\text { B } \\
\text { N.S. }\end{array}$ & $\begin{array}{c}\text { A } \\
\text { N.S. }\end{array}$ & $\begin{array}{c}\text { A } \\
\text { N.S. }\end{array}$ & $\begin{array}{c}\text { B } \\
3.75 .\end{array}$ & $\begin{array}{l}\text { AB } \\
\text { N.S. }\end{array}$ & $\begin{array}{c}\text { A } \\
0.73\end{array}$ & $\begin{array}{c}\text { B } \\
3.38 \\
\end{array}$ & $\begin{array}{l}\text { AB } \\
\text { N.S. }\end{array}$ \\
\hline \multicolumn{13}{|c|}{ Number of branches/plant } \\
\hline Healthy & 12.33 & 12.33 & 12.33 & 17.67 & 17.67 & 17.67 & 11.67 & 11.67 & 11.67 & 16.33 & 16.33 & 16.33 \\
\hline Infected & 8.00 & 8.00 & 8.00 & 13.00 & 13.00 & 13.00 & 10.00 & 10.00 & 10.00 & 14.33 & 14.33 & 14.33 \\
\hline L. grass & 10.66 & 12.00 & 11.33 & 16.00 & 17.33 & 16.67 & 11.33 & 14.00 & 12.67 & 16.67 & 17.67 & 17.17 \\
\hline Peppermint & 11.33 & 15.33 & 13.33 & 18.33 & 20.66 & 19.50 & 14.33 & 14.67 & 14.50 & 23.67 & 20.0 & 21.83 \\
\hline & 13.33 & 17.33 & 15.33 & 17.66 & 22.66 & & 12.33 & 18.33 & 15.33 & 20.0 & 25.67 & 22.83 \\
\hline 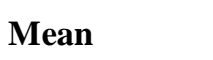 & 11.13 & 13.0 & - & 16.53 & 18.26 & - & 11.93 & 13.73 & - & 18.20 & 18.8 & - \\
\hline L.S.D. & $\begin{array}{c}\text { A } \\
0.76 \\
\end{array}$ & $\begin{array}{c}\text { B } \\
0.85 \\
\end{array}$ & $\begin{array}{l}\mathrm{AB} \\
1.20 \\
\end{array}$ & $\begin{array}{c}\mathrm{A} \\
1.68 \\
\end{array}$ & $\begin{array}{c}\mathrm{B} \\
0.86 \\
\end{array}$ & $\begin{array}{l}\mathrm{AB} \\
1.21 \\
\end{array}$ & $\begin{array}{c}\mathrm{A} \\
1.49 \\
\end{array}$ & $\begin{array}{c}\mathrm{B} \\
0.82 \\
\end{array}$ & $\begin{array}{l}\mathrm{AB} \\
1.16 \\
\end{array}$ & $\begin{array}{c}\text { A } \\
\text { N.S. }\end{array}$ & $\begin{array}{c}\mathrm{B} \\
0.97 \\
\end{array}$ & $\begin{array}{l}\mathrm{AB} \\
1.38 \\
\end{array}$ \\
\hline \multicolumn{13}{|c|}{ Fresh weight (g/plant) } \\
\hline Hea & 268.1 & 268.1 & 268.1 & 344.1 & 344.1 & 344.1 & 264.3 & 264.3 & 264.3 & 323.1 & 323.1 & 323.1 \\
\hline Infected & 235.1 & 235.1 & 235.1 & 285.4 & 285.4 & 285.4 & 245.5 & 245.5 & 245.5 & 290.5 & 290.5 & 290.5 \\
\hline L. grass & 237.1 & 267.9 & 252.5 & 319.7 & 322.2 & 320.9 & 246.8 & 310.2 & 278.5 & 306.7 & 370.2 & 338.4 \\
\hline Peppermint & 286.8 & 290.6 & 288.7 & 397.3 & 411.3 & 404.3 & 343.6 & 315.9 & 329.8 & 450.3 & 440.7 & 445.5 \\
\hline Rosemary & 275.9 & 315.8 & 295.9 & 359.5 & 475.0 & 417.3 & 290.6 & 379.9 & 335.3 & 388.1 & 474.8 & 431.4 \\
\hline Mean & 260.6 & 275.5 & - & 341.2 & 367.6 & - & 278.2 & 303.2 & - & 351.7 & 379.8 & - \\
\hline L.S.D.at 5\% & $\begin{array}{c}\text { A } \\
3.59\end{array}$ & $\begin{array}{c}B \\
2.93 \\
\end{array}$ & $\begin{array}{l}\mathrm{AB} \\
4.15\end{array}$ & $\begin{array}{c}\mathrm{A} \\
4.50 \\
\end{array}$ & $\begin{array}{c}\mathrm{B} \\
4.17 \\
\end{array}$ & $\begin{array}{l}\mathrm{AB} \\
5.89 \\
\end{array}$ & $\begin{array}{c}\text { A } \\
3.56\end{array}$ & $\begin{array}{c}\mathrm{B} \\
4.25 \\
\end{array}$ & $\begin{array}{l}\mathrm{AB} \\
6.01\end{array}$ & $\begin{array}{c}\mathrm{A} \\
4.96\end{array}$ & $\begin{array}{c}\text { B } \\
3.61 \\
\end{array}$ & $\begin{array}{c}\mathrm{AB} \\
5.11\end{array}$ \\
\hline
\end{tabular}

$T_{1}$ : treatment with essential oils before inoculation with virus, $T_{2}$ : treatment with essential oils after inoculation with virus, $A B$ revealed to compare the means for the same level of $T_{1}$ or $T_{2}$. 
Table 3. Effect of essential oils treatments on dry weight (g/plant) and essential oil \% of infected Ocimum basilicum L. during 2013 and 2014 seasons.

\begin{tabular}{|c|c|c|c|c|c|c|c|c|c|c|c|c|}
\hline \multirow{4}{*}{$\begin{array}{l}\text { Treatments } \\
\text { (B) }\end{array}$} & \multicolumn{11}{|c|}{ Dry weight (g/plant) } & \\
\hline & \multicolumn{6}{|c|}{ First season } & \multicolumn{6}{|c|}{ Second season } \\
\hline & \multicolumn{3}{|c|}{ First cut } & \multicolumn{3}{|c|}{ Second cut } & \multicolumn{3}{|c|}{ First cut } & \multicolumn{3}{|c|}{ Second cut } \\
\hline & $\begin{array}{l}\text { T1 } \\
\text { (A) }\end{array}$ & $\mathbf{T} 2$ & Mean & T1 & T2 & Mean & T1 & A) & Mea & T1 & (A) ${ }^{\mathrm{T} 2}$ & Mean \\
\hline Healthy & 68.23 & 68.23 & 68.20 & 79.5 & 79.50 & 79.5 & 67.12 & 67.12 & 67.1 & 76.92 & 76.92 & 76.92 \\
\hline Infected & 50.73 & 50.73 & 50.73 & 69.83 & 69.83 & 69.83 & 58.67 & 58.67 & 58.6 & 72.40 & 72.40 & 72.49 \\
\hline L. grass & 55.37 & 67.2 & 61.4 & 76.0 & 77.20 & 76.60 & 58.63 & 74.06 & 66.3 & 79.35 & 82.19 & 80.77 \\
\hline Peppermint & 70.43 & 72.43 & 71.43 & 85.5 & 88.27 & 86.88 & 79.88 & 76.25 & 78.0 & 90.97 & 90.04 & 90.51 \\
\hline Rosemary & 69.30 & 77.07 & 73.18 & 82.5 & 95.50 & 89.0 & 70.43 & 81.33 & 75.8 & $8 \quad 85.88$ & 100.69 & 93.29 \\
\hline Mean & 62.81 & 67.17 & - & 78.67 & 82.06 & - & 66.95 & 71.49 & - & 81.1 & 84.45 & - \\
\hline L.S.D. at $5 \%$ & $\begin{array}{c}\mathrm{A} \\
1.77\end{array}$ & $\begin{array}{c}\mathrm{B} \\
1.31\end{array}$ & $\begin{array}{l}\mathrm{AB} \\
1.86\end{array}$ & $\begin{array}{c}\text { A } \\
0.63\end{array}$ & $\begin{array}{c}B \\
2.1\end{array}$ & $\begin{array}{l}\mathrm{AB} \\
2.98\end{array}$ & $\begin{array}{c}\mathrm{A} \\
1.68\end{array}$ & $\begin{array}{c}\mathrm{B} \\
1.93\end{array}$ & $\begin{array}{l}\mathrm{AB} \\
2.73\end{array}$ & $\begin{array}{c}\text { A } \\
2.30\end{array}$ & $\begin{array}{c}\text { B } \\
3.15\end{array}$ & $\begin{array}{l}\mathrm{AB} \\
4.45\end{array}$ \\
\hline \multicolumn{13}{|c|}{ Oil ( \% ) } \\
\hline Healthy & 1.20 & 1.253 & 1.20 & 1.227 & 1.307 & 1.267 & 1.147 & 1.20 & 1.1 & 1.173 & 1.253 & 1.213 \\
\hline Infected & 0.907 & 0.987 & 0.947 & 1.00 & 1.027 & 1.013 & 0.827 & 0.88 & 0.8 & 0.88 & 0.933 & 0.907 \\
\hline L. grass & 1.040 & 1.093 & 1.067 & 1.107 & 1.120 & 1.113 & 0.933 & 0.96 & 0.9 & 0.96 & 1.120 & 1.040 \\
\hline Peppermint & 1.077 & 1.120 & 1.093 & 1.147 & 1.173 & 1.160 & 1.040 & 1.04 & 1.0 & $10 \quad 1.093$ & 1.147 & 1.120 \\
\hline Rosemary & 1.227 & 1.280 & 1.253 & 1.280 & 1.304 & 1.293 & 1.200 & 1.23 & 1.2 & $3 \quad 1.229$ & 1.28 & 1.253 \\
\hline Mean & 1.088 & 1.147 & - & 1.152 & 1.187 & - & 1.029 & 1.06 & - & 1.067 & 1.147 & - \\
\hline L.S.D.at 5\% & $\begin{array}{c}\text { A } \\
\text { N.S }\end{array}$ & $\begin{array}{c}\text { B } \\
0.069\end{array}$ & $\begin{array}{l}\text { AB } \\
\text { N.S }\end{array}$ & $\begin{array}{c}\mathrm{A} \\
0.012\end{array}$ & $\begin{array}{c}\text { B } \\
0.079\end{array}$ & $\begin{array}{l}\text { AB } \\
\text { N.S }\end{array}$ & $\begin{array}{c}\text { A } \\
\text { N.S }\end{array}$ & $\begin{array}{c}\text { B } \\
0.086\end{array}$ & B &.$S \begin{array}{c}\mathrm{A} \\
0.069\end{array}$ & $\begin{array}{c}\mathrm{B} \\
0.081\end{array}$ & $\begin{array}{l}\text { AB } \\
\text { N.S }\end{array}$ \\
\hline
\end{tabular}

$T_{1}$ : treatment with essential oils before inoculation with virus, $T_{2}$ : treatment with essential oils after inoculation with virus, $A B$ revealed to compare the means for the same level of $T_{1}$ or $T_{2}$.

organoleptic properties and thus quality of EO were severely affected and EO composition resulted was severely altered. Many diseases afflict basil and it is noteworthy that quali-quantitative modifications of secondary metabolites, hereby included essential oils, can be related to the phytopathological status of plants (Bruni et al., 2005). The effect of phytopathogenic viruses on various aromatic plants has been found to be responsible for significant variations in the composition of marketed essential oil (Hudaib et al., 2002). High level of emission of this monoterpenes (linalool) has been demonstrated to repel significantly Myzus persicae aphid, one of the major AMV vectors (Aharoni et al., 2003). The reduction of linalool in the AMV-infected basil, combined with the bright yellow mosaic symptoms elicited by the same virus in this plant, eugenol presents also a strong repellent activity against mosquito (Nerio et al., 2010).

The effects of oil treatments before and after inoculation with CMV on essential oil content and composition of a sweet basil were evaluated (Table 4 and Fig. 2) and superior performance of rosemary essential oil regarding oil yield and composition of basil as compared to other treatments was recorded. The significant increase in total identified of essential oil composition of basil plant was 88.43 and $86.09 \%$ directly related to the treatment with rosemary oil before and after inoculation respectively, compared to untreated infected plants, with increase in myrcene from 0.78 to $7.41 \%$, and linalool from 33.09 to $46.21 \%$, when 


\section{F.E.M Saleh et al.}

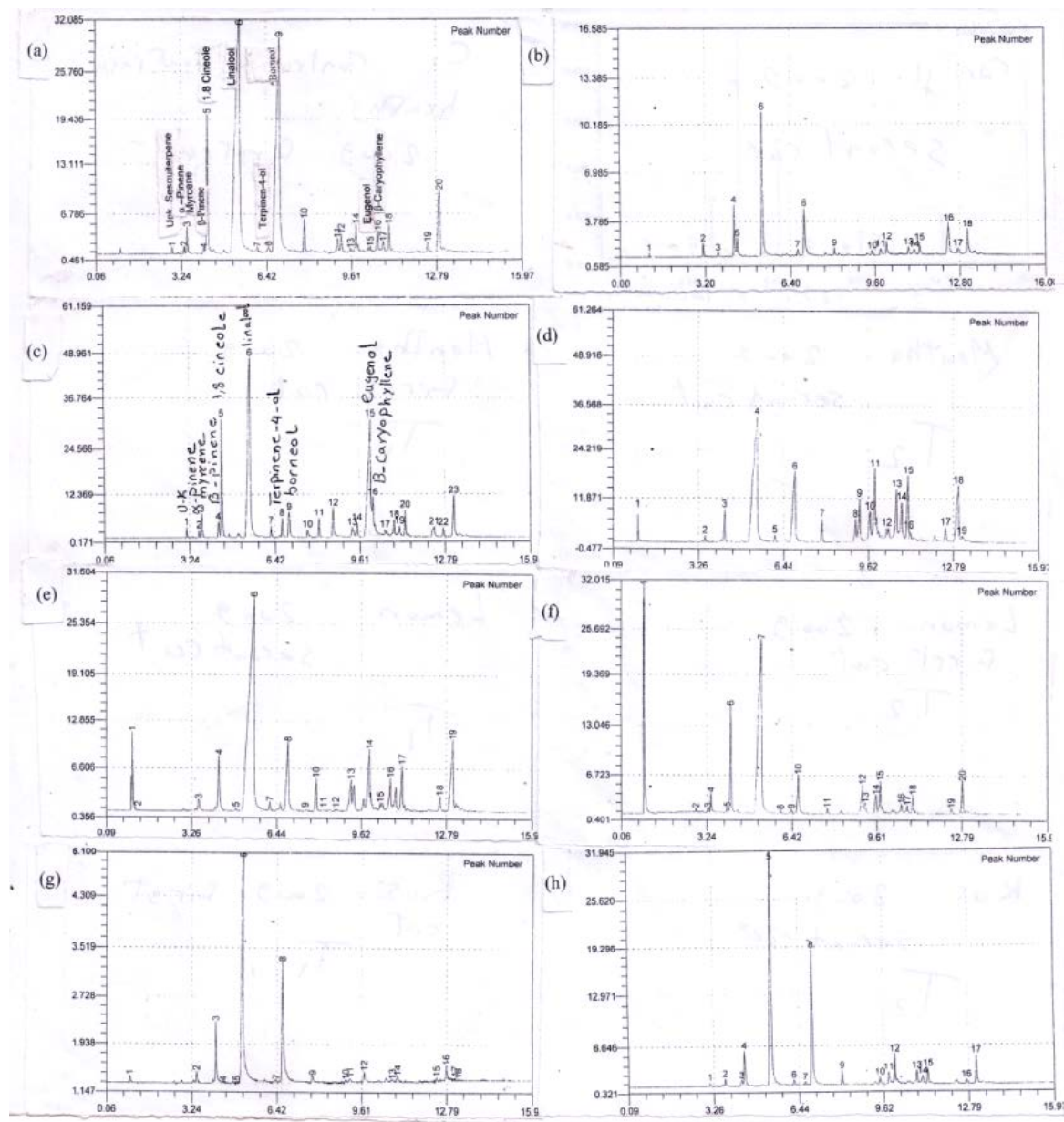

Fig. 2. Consequences of CMV infection and essential oil treatments on some of sweet basil essential oil compounds.

Each column represents the sum of RA\% (relative area percentage) for top ten compounds (sesquiterpenes, myrcene, beta- pinene, linalool ,1,8-cineole, alpha-pinene, , terpinene-4-ol, borneol, eugenol, and Bcaryophyllene) fractions in healthy (a), CMV-infected (b) and plants treated with peppermint (c) and(d), lemongrass (e) and(f) and rosemary (g) and (h) essential oils at 1\% concentration, before and after inoculation with virus respectively.

applied before inoculation and with a great increase in 1,8-cineole (from 2.96 to $52.58 \%$ ) when applied after inoculation, despite a slight decrease was recorded in eugenol before and after inoculation. The great changes in the chemical composition of the basil essential oil related to peppermint oil treatment comparable to untreated infected plants. When it was applied, a great increase was recorded in eugenol (from 2.82 to $25.26 \%$ and 5.46 before and after inoculation, respectively). However the increase in myrcene was from 0.78 to 1.44 and $2.24 \%$ before and after inoculation, respectively, and the increase in 1,8-cineole
\% from 2.96 to 8.68 were resulted before inoculation. The chemical composition of essential oils determined may bring about significant changes in the production of secondary metabolites (Lima et al., 2003; Gobbo-Neto and Lopes, 2007). Ismail (1994) studied the antiviral activity of lemongrass and 3 other essential oils against potato virus $\mathrm{Y}$ in vitro and in vivo, lemongrass oil was found to be the most effective followed by geranium oil then spearmint and peppermint oils. This superiority of clove oil effects may be due to that it works as a high quality antioxidant and reduces peroxidase enzyme activity (Ponce et al., 2004 a and b). 


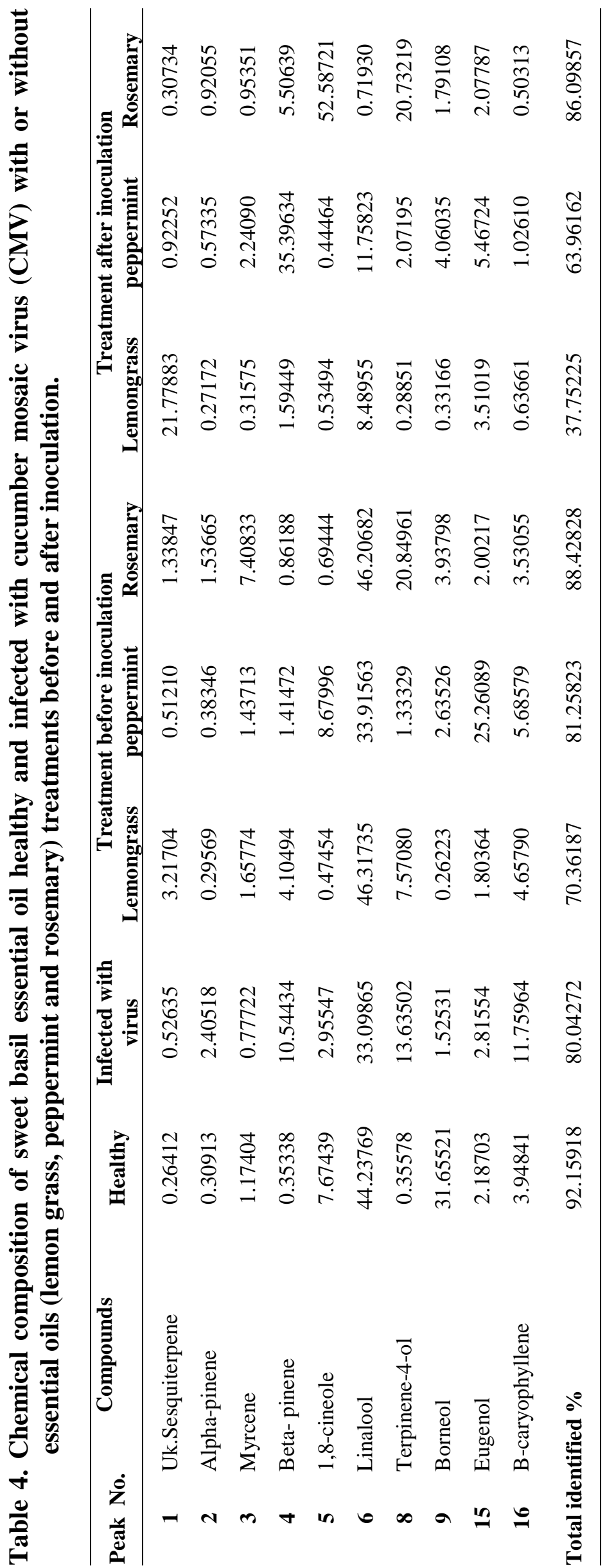




\section{F.E.M Saleh et al.}

The possible mode of action is by inducing the plant to secrete more peroxidase enzyme which increases the resistance of the plant to the viral attack and its spread from cell to cell (Edris and Mahmoud, 2003).

\section{CONCLUSION}

In this study, identification of the natural occurrence of cucumber mosaic virus of basil, a Lamiaceae host plant in Egypt was reported, and indicated that the essential oils isolated from rosemary, peppermint and lemongrass, at $1 \%$ concentration had the potential to be used as an effective alternative for the treatment of basil plants with CMV in vivo and prevent the spread of virus infections, improved yield and oil content and its composition, because they contain a range of bioactive components present in oil or the oil as such may be used as ecofriendly and natural antiviral products on commercial scales. Application of essential oil and their components is a very attractive method for controlling plant diseases, gaining increasing interest because of their relatively safe, their wide acceptance by consumers, and their exploitation for potential multi-purpose functional uses.

\section{REFERENCES}

Abd Alla, M.A. and El-Shoraky, F.S. (2017). Impact of biological agents and plant essential oils on growth, quality and productivity of cabbage and cauliflower plants correlated to some diseases control. J. Sus. Agri. Sci., 43(1):27-38.

Abdulla, O.A. and Ali, A. (2012). Genetic diversity in the 3- terminal region of papay ring spot virus (PRSV-W) isolates from watermelon in Oklahoma. Archive of Virology, 157(3):405-412.

Aharoni, A.; Giri, A.P.; Deuerlein, S.; Griepink, F.; de Kogel, W.J.; Verstappen, F.W.; Verhoeven, H.A.; Jongsma, M.A., Schwab, W. and Bouwmeester, H.J. (2003). Terpenoid metabolism in wild-type and transgenic Arabidopsis plants. Plant Cell, 15:28662884.
Akhila, A. (2010). Essential Oil-bearing Grasses: The Genus Cymbopogon. Medical and Aromatic Plants-Industrial Profile. Taylor and Francis Group, L.L.C.

Balachandran, S.; Hull, R.J.; Martins, R.A.; Vaadia, Y. and Lucas, W.J. (1997). Influence of environmental stress on biomass partitioning in transgenic tobacco plants expressing the movement protein of tobacco mosaic virus. Plant Physiology, 114:475-481.

Black,C.A.; Evans, D.D.; Nhite, J.I.; Ensminger, L.E. and Clark, F.E. (1982). Methods of Soil Analysis. J.Amer.Soc. Agron. Inc. Madison, Wisconsin U.S.A.

British Pharmacopoeia (1973). The Pharmaceutical Society of Great Britain. 10th ed. London: The Pharmaceutical Press, 1973. xxxlx + 983 page.

Bruni, M.; Bellardi, G. and Parrella, G. (2016). Change in Chemical Composition of Sweet Basil (Ocimum basilicum L.) Essential Oil Caused by Alfalfa mosaic virus. J Phytopathol 164:202-206.

Bruni, R.;Pellati, F.; Bellardi, M.G.; Benvenuti, S.; Paltrinieri, S.; Bertaccini, A. (2005).Herbal drug quality and phytochemical composition of Hypericum perforatum L. affected by ash yellows phytoplasma infection. J. Agric. Food Chem., 53:964-968.

Duffus, J.E.; Liu, H.Y. and Wisler, G.C. (1996). Tomato infectious chlorosis virus-a new clostero-like virus transmitted by Trialeurodes vaporariorum. Eur. J. Plant Pathol., 102:219-226.

Edris, A.E. and Mahmoud, S.Y.M. (2003). Relationship between certain volatile components of lemongrass oil and its antiviral activities against bean yellow mosaic potyvirus.Bull.NRC, Egypt, 28(3):289-299.

Font, M.I.; Juarez, M.; Martinez, O. and Jorda, C. (2004). Current status and 
newly discovered natural hosts of Tomato infectious chlorosis virus and tomato chlorosis virus in Spain. Plant Dis., 88:82.

Gobbo-Neto L. and Lopes, N.P. (2007). Plant as medicinais fatores de influência no conteúdo de metabólitos secundários. Quim. Nova, 30: 374-381.

Gracindo, L. A.M.B.; Grisi, M.C.M.; Silva, D.B.; Alves, R.B.N. ; Bizzo, H.R. and Vieira, R.F. (2006). Chemical characterization of mint (Mentha spp.) germplasm at Federal District, Brazil. Rev. Bras. Pl. Med., Botucatu, 8:5-9.

Hudaib, M.; Bellardi, M.G.; RubiesAutonell, C. Fiori, J. and Cavrini, V. (2001). Chromatographic (GC-MS, HPLC) and virological evaluations of Salvia sclarea infected by BBWVI. Farmaco., 56:219-227.

Hudaib, M.; Cavrini, V.; Bellardi, M.G. and Rubies-Autonell, C. (2002). Characterization of the essential oils of healthy and virus infected Echinacea purpurea (L.) Moench plants. J Essent Oil Res., 14:427-430.

Ismail, M.H. (1994). Essential oils as inhibitors of potato virus Y. Egyptian Journal of Botany, 34(2):167-176.

Jackson, M.L. (1973). Soil Chemical Analysis. Prentice-Hal Inc., Engewood Cliffs, New Jersey.

Kaledin, V.I.; Pakharukova, M.Y.; Pinovarova, E.N; Kropachev, K.Y.; Baginskaya, N.V.; Vasilieva, E.D.; Ilnitskaya, S.I.; Nikitenko, E.V.; Kobzev, V.F. and Merkulova, T.I. (2009). Correlation between hepatocarcinogenic effect of estragole and its influence on glucocorticoid induction of liver-specific enzymes and activities of FOXA and HNF4 transcription factors in mouse and rat liver. Biochem (Moscow), 74:377-384.

Khan, A.A.; Sharma, R.; Afreen, B.; Naqvi, Q.A.; Kumar, S.; Snehi, S.K. and Raj, S.K. (2011). Molecular identification of a new isolate of cucumber mosaic virus subgroup II from basil (Ocimum sanctum) in India. Phytoparasitica, 39:199-203.

Lima, H.R.P; Kaplan, M.A.C. and Cruz, A.V.M. (2003). Influência dos fatores abióticos na produção e variabilidade de terpenóides em plantas. Floresta e Ambiente, 10:71-77.

Lucas, W.J.; Olesinski; A.A.; Hull, R.J.; Haudenshield, J.S.; Deom, C.M.; Beachy, R.N. and Wolf, S. (1993). Influence of the tobacco mosaic virus $30-\mathrm{kDa}$ movement protein on carbon metabolism and photosynthate partitioning in transgenic tobacco plants. Planta, 190:88-96.

Marini, E. (1955). Una virosi apparsa sul basilica (Ocimum basilicum). Rivista dell Ortoflorofrutticultura Italiana, 39:360-362.

Milojevic, K.; Stankovic, K.I.; Vucurovic, A.; Ristic, D.; Nikolic, D.; Bulajic, A. and Krstic, B. (2010). First report of cucumber mosaic virus infecting watermelon in Serbia. Plant Disease, 96:1706.

Moghadam, A.R.L. (2015). Antioxidant activity and chemical composition of Rosmarinus officinalis L. essential oil from Iran. journal Of Essential Oil Bearing Plants, 18(6):1490-1494

Nerio, L.S.; Olivero-Verbel, J. and Stashenko, E. (2010). Repellent activity of essential oils: a review. Bioresour Technol., 101:372-378.

Niakan, N. and Saberi, K. (2009). Effects of Eucalyptus allelopathy on growth characters and antioxidant enzymes activity in Phalaris weed. Asian J. Plant Sci., 8(6):440-446.

Ponce, G.; del Valle, C. and Roura, S.I. (2004a). Shelf life of leafy vegetables treated with natural essential oils. J. Food Sci., 69(2):50-56 


\section{F.E.M Saleh et al.}

Ponce, G., del Valle, C. and Roura, S.I. (2004b). Natural essential oils as reducing agents of peroxidase activity in leafy vegetables. LWT. Food Sci. \& Techno., 37(2):199-204.

Raj, S.K.; Chandra, G. and Singh, B.P. (1997). Some Indian strains of cucumber mosaic virus lacking satellite RNA. Indian Journal of Experimental Biology, 35:1128-1131

Shalitin, D.; Wang Y.; Omid, A.; Gal-On, A. and Wolf, S. (2002). Cucumber mosaic virus movement protein affects sugar metabolism and transport in tobacco and melon plants. Plant Cell and Environment, 25:989-997.

Snedecor, GW. And W.G.Cochran (1973). Statistical Methods. Sixth Edition. Iowa State Univ Press, Ames, Iowa,USA.

Tajidin, N.E.; Ahmad, S.H; Rosenani, A.B.; Azimah, H. and Munirah, M. (2012). Chemical composition and citral content in lemongrass (Cymbopogon citratus) essential oil at three maturity stages. African Journal of Biotechnology, 11(11):2685-2693.

Wintermantel, W.M. and Natwick, E.T. (2012). First report of alfalfa mosaic virus infecting basil (Ocimum basilicum) in California. Plant Disease, 96(2):295.

Zhao, L.; Feng, C.; Wu, K.; Chen, W.; Chen,Y. ; Hao, X. and Wu, Y. (2017). Advances and prospects in biogenic substances against plant virus: A review Pesticide Biochemistry and Physiology, 135:15-26.

Zhu, S.F. and Qiu, W.F. (1989). A primary study of the therapeutic effects of some medicinal herb extracts on the pepper mosaic caused by CMV, Acta Phytopathol. Sin., 19:123-128.

$$
\begin{aligned}
& \text { دراسات على مرض موزيك فيروس الريحان و مقاومته باستخدام بعض الزيوت الطيار } \\
& \text { فل الندى محمد صالح"، عاطف عبده سيد* و أمال محمد ابراهيم عراقى ** } \\
& \text { * قسم بحوث النباتات الطبية و العطرية، معهد بحوث البساتين، مركز البحوث الزر اعية، الجيزة، مصر. } \\
& \text { ** قسم أمر اض النبات، كلية الزر اعة، جامعة أسيوط، مصر البحر. }
\end{aligned}
$$

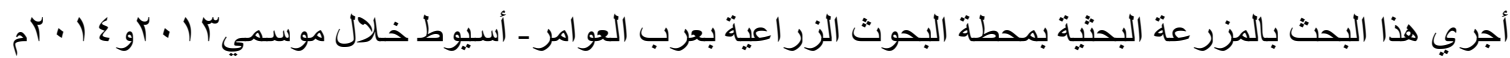

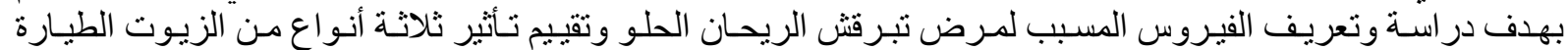

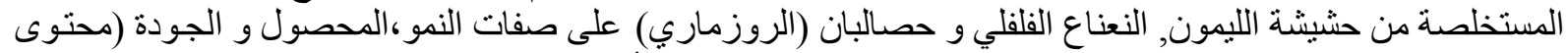

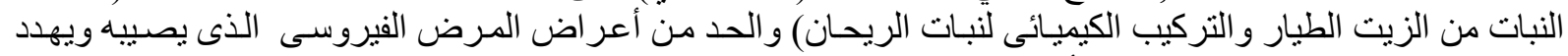
زر اعته في كثير من الاماكن بمحافظة أسيوط.

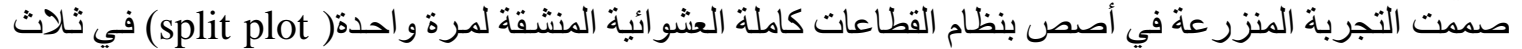

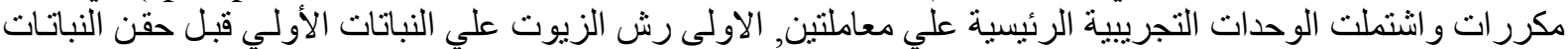

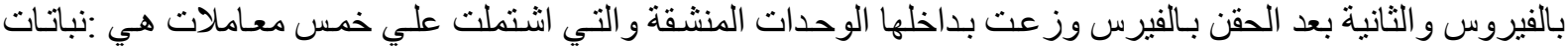

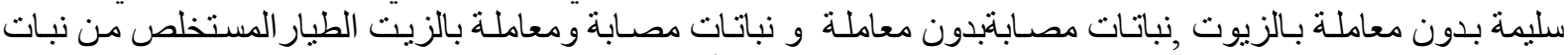

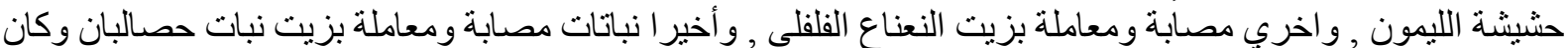

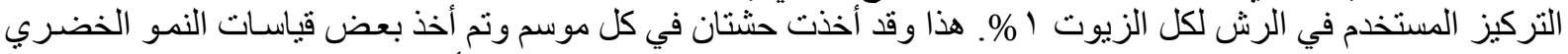

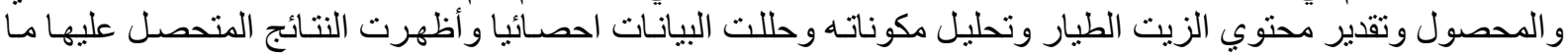
ا ـ أن الفيروس المسبب لتبرفش الريحسان الحلو باستخدام البريمر الخاص وبطريقة (RT-PCR) هو فيروس 


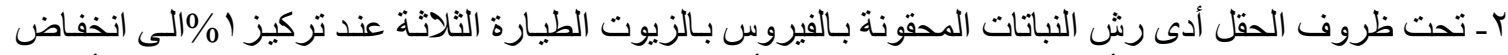

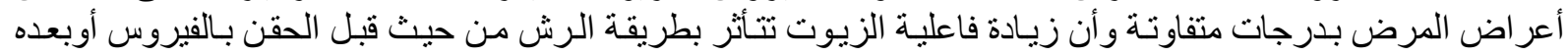

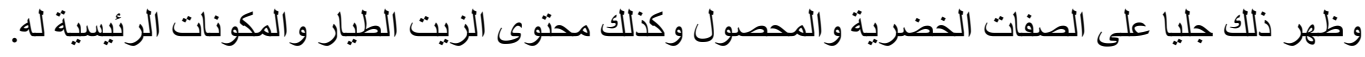

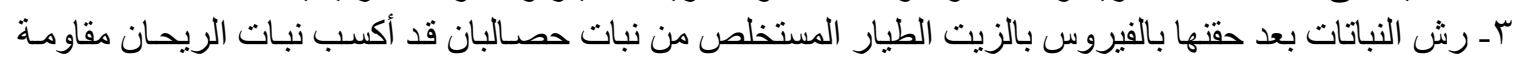

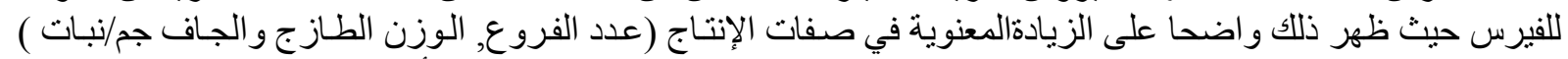

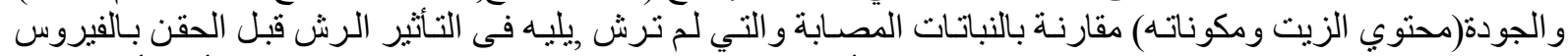

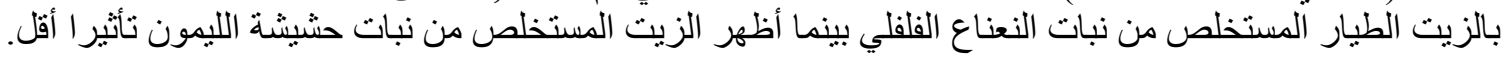

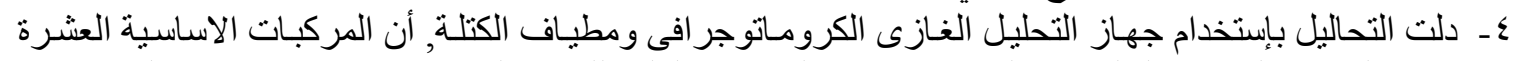

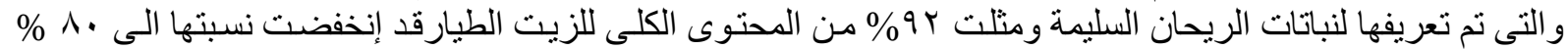
نتيجة لإصابتها بالفيروس. تصنات الريات

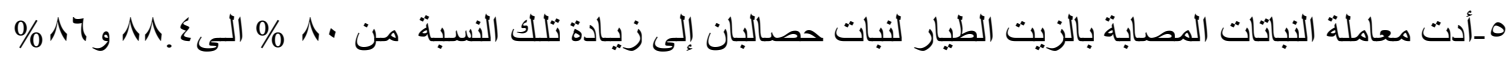

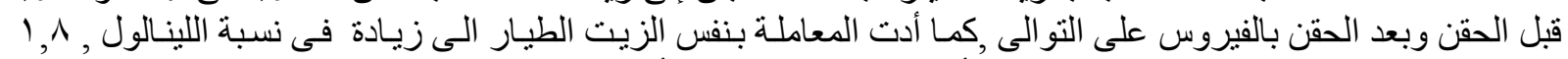

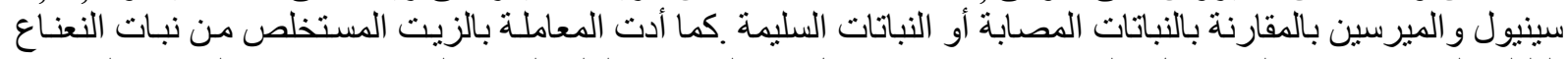

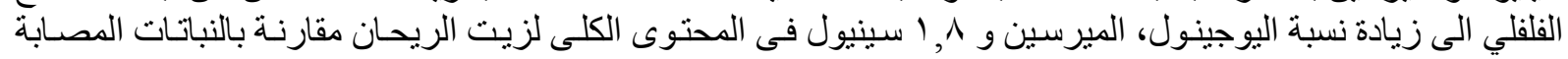

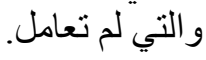

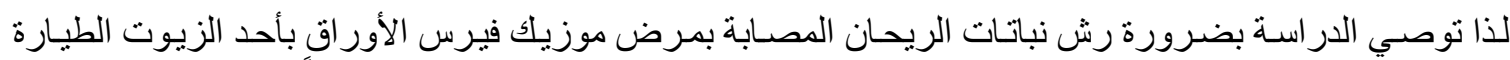

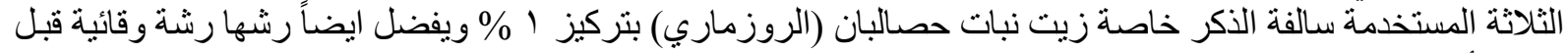

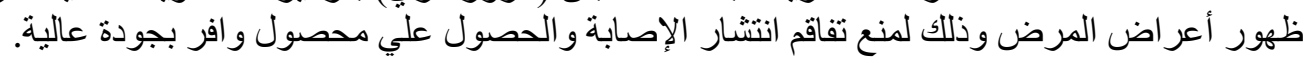




